\title{
Flow field in a reservoir subject to pumped-storage operation - in situ measurement and numerical modeling
}

\author{
Michael Müller, Giovanni De Cesare \& Anton J. Schleiss
}

To cite this article: Michael Müller, Giovanni De Cesare \& Anton J. Schleiss (2018)

Flow field in a reservoir subject to pumped-storage operation - in situ measurement and numerical modeling, Journal of Applied Water Engineering and Research, 6:2, 109-124, DOI:

10.1080/23249676.2016.1224692

To link to this article: https://doi.org/10.1080/23249676.2016.1224692

\section{曲 Published online: 06 Sep 2016.}

Submit your article to this journal $₫$

Џ Article views: 121

Q View related articles $\square$

View Crossmark data ¿

4 Citing articles: 4 View citing articles 


\title{
Flow field in a reservoir subject to pumped-storage operation - in situ measurement and numerical modeling
}

\author{
Michael Müller (10 ${ }^{\mathrm{a} \dagger}$, Giovanni De Cesare $\mathbb{1}^{\mathrm{b} *}$ and Anton J. Schleiss ${ }^{\mathrm{b}}{ }^{\mathrm{b}}$ \\ ${ }^{a}$ IUB Engineering Ltd., Belpstrasse 48, CH-3007 Bern, Switzerland; ${ }^{b}$ Laboratory of Hydraulic Constructions (LCH), Ecole \\ Polytechnique Fédérale de Lausanne (EPFL), Station 18, CH-1015 Lausanne, Switzerland
}

(Received 11 December 2015; accepted 2 August 2016)

\begin{abstract}
In pumped-storage reservoirs, turbulent kinetic energy input from plant operation can be considerably high. Flow velocities were measured by Acoustic Doppler Current Profilers near the intake/outlet structure to describe flow patterns induced by pumped-storage operation in an Alpine reservoir. Recorded data allowed reproducing 1D and 2D velocity profiles along the water column. The comparison between the main frequencies of the velocity signal and the discharge series from the plant reveals correlation between recorded flow patterns and pumped-storage operation. Numerical modeling enhanced the understanding of flow patterns developing near the intake/outlet structure. Both results reveal that water withdrawal by pumping only marginally affects flow patterns in front of the intake, whereas water injected during turbine mode leads to backflow areas and large-scale recirculation cells. Numerical modeling further revealed that steady flow patterns are developing only after some $2.5 \mathrm{~h}$ of continuous turbine operation.
\end{abstract}

Keywords: flow patterns; flow velocities; intake/outlet structure; Acoustic Doppler Current Profilers; pumped-storage hydropower plant; reservoir sedimentation

Notation
Symbols
$A$
$A_{i, \mathrm{eff}}$
$C_{\mathrm{k}}^{*}$

$D$
$f$
$H$
$P$
$P_{v \mathrm{E}, \mathrm{N}}$
$P_{Q}$
$p$
$Q$
$T$
$t$
$U, v$
$V$
$x^{\prime}$
$x$
$y$
$y^{\prime}$

\section{Notation}

area $\left(\mathrm{m}^{2}\right)$

effective in-/outflow section $\left(\mathrm{m}^{2}\right)$

efficiency factor, converting wind to turbulent kinetic energy $(-)$

diameter $(\mathrm{m})$

frequency $(\mathrm{Hz})$

height (m)

precipitation (mm)

power of sampled velocity signal $(\mathrm{mm} / \mathrm{s})^{2}$

power of sampled discharge signal $\left(\mathrm{m}^{3} / \mathrm{s}\right)^{2}$

pressure $(\mathrm{m})$

discharge $\left(\mathrm{m}^{3} / \mathrm{s}, 1 / \mathrm{s}\right)$

temperature $\left({ }^{\circ} \mathrm{C}\right)$

time (s)

velocity $(\mathrm{m} / \mathrm{s})$

volume $\left(\mathrm{m}^{3}\right)$

longitudinal coordinate in the intake's local referential (m)

abscissa (m)

ordinate $(\mathrm{m})$

Transverse coordinate in the intake's local referential (m)
$Z \quad$ vertical coordinate in Swiss grid (m)

$\Delta t \quad$ time step (s)

$\eta_{\text {Turb }} \quad$ turbulent kinetic energy input per unit of area and time $\left(\mathrm{W} / \mathrm{m}^{2}\right)$

$\eta_{\mathrm{a}} \quad$ natural turbulent kinetic energy input per unit of area and time $\left(\mathrm{W} / \mathrm{m}^{2}\right)$

$v \quad$ kinematic viscosity $\left(\mathrm{m}^{2} / \mathrm{s}\right)$

$\rho \quad$ density $\left(\mathrm{kg} / \mathrm{m}^{3}\right)$

\section{Indices}

0 initial

a air, wind

E East

Gr Grimsel

i intake

L longitudinal

$m$ mean

N North

Oa Oberaar

Pump pumping

T transversal

Turb turbine

turb turbulent

w water

\footnotetext{
*Corresponding author. Email: giovanni.decesare@epfl.ch

${ }^{\dagger}$ Formerly at LCH-EPFL.
} 


\section{Introduction}

\section{Context}

Over the last decades, pumped-storage hydropower plants have gained in importance since they allow short-term regulation of the power grid, storing energy during low demand and generating peak electricity. Such facilities normally consist of two reservoirs at different elevations, between which water is moved up and down. Like in traditional storage hydropower plants, these reservoirs can be affected by sedimentation processes if they are fed by natural inflow (rivers and direct runoff from the valley flanks) which transports sediment into the storage volume. This filling up of the reservoir reduces storage capacity and affects the operational and structural safety of the plant (Graf 1982; ICOLD 1989; Schleiss et al. 2010). In pumped-storage reservoirs, sediment inflow can also result from the connection of two initially separated systems, that is, particles can be transferred from one reservoir to the other. For example, even fully artificial reservoirs with any natural sediment input can be subject to sedimentation problems, as they are supplied with sediment-laden water from the other connected upper or lower reservoir. In the framework of a Ph.D. thesis, Müller (2012) investigated a new approach of keeping fine particles in suspension, namely with the goal of benefitting from the turbulence induced by pumped-storage cycles to hinder fast settling and to improve sediment transfer through the power intakes and bottom outlets toward the downstream reach. This paper presents the results of a prototype monitoring campaign, aimed at describing the flow conditions in front of the intake/outlet structure of an Alpine pumped-storage plant.

\section{Motivation}

With increasing pumped-storage activity, especially the areas in the vicinity of intake and outlet structures are subjected to fast and frequent changes in flow conditions. When water is ejected into the reservoir, turbulent flow conditions are generated due to the inflowing jet. During water withdrawal from the reservoir, a potential flow field develops, characterized by fast-decreasing flow velocities with increasing distance from the intake. Physical and chemical properties of the involved water bodies can be significantly altered (Potter et al. 1982). The mixing processes due to pumped-storage operation were shown to weaken thermal stratification and hence affect nutrients and ecosystems in reservoirs and downstream rivers (Girgidov et al. 1990; US Bureau of Reclamation 1993; Finger et al. 2007). Imboden (1980) developed a mathematical model of vertical temperature structure and predicted a shift of seasonal thermal stratification of Lake Lucerne (Switzerland) due to a hypothetical pumped-storage plant. Fine sediment behavior can be affected by the plant operation as well. Settling of small particles in the water body near the intake/outlet occurs if flow velocities are tending to very low values, that is, when energy available for mixing is insufficient. In some cases, the turbulent kinetic energy (TKE) input from power plants is high enough to keep small particles in suspension or even resuspend fine sediment from the reservoir bottom (US Bureau of Reclamation 1993). Wolanski et al. (1992) presented an application in maritime turbulence-induced mixing.

To estimate TKE input $\eta_{\text {Turb }}$ induced by power generation, Imboden (1980) gives the following formula (adapted):

$$
\eta_{\mathrm{Turb}}=\frac{Q_{\mathrm{Turb}} \cdot U_{\mathrm{Turb}}^{2} \cdot \rho_{\mathrm{IN}}}{2 \cdot A_{0}},
$$

where $Q_{\text {Turb }}$ : the turbine discharge $\left(\mathrm{m}^{3} / \mathrm{s}\right), U_{\text {Turb }}$ : the efflux velocity at the intake $(\mathrm{m} / \mathrm{s}), \rho_{\mathrm{IN}}$ : the density of injected water $\left(\mathrm{kg} / \mathrm{m}^{3}\right)$ and $A_{0}$ : the lake surface area $\left(\mathrm{m}^{2}\right)$.

For maximum discharge of $Q_{\text {Turb }}=93 \mathrm{~m}^{3} / \mathrm{s}$ and the Lake Grimsel area of $2.63 \mathrm{~km}^{2}$, an energy input of $\eta_{\text {Turb }}=7.4 \times 10^{-3} \mathrm{~W} / \mathrm{m}^{2}$ is calculated. Taking into account an average turbine operation of $6.5 \mathrm{~h} / \mathrm{d}$, the daily mean TKE input is of $\eta_{\text {Turb }}=2 \times 10^{-3} \mathrm{~W} / \mathrm{m}^{2}$. As TKE input from natural convective mixing or pumping activity has low influence on mixing of the water column (Anderson 2010), it has not been considered in the present calculation. The artificial TKE input can be compared to the natural TKE input per unit area and time due to average wind-forcing (Anderson 2010):

$$
\eta_{\mathrm{a}}=C_{\mathrm{k}}^{*} \cdot \rho_{\mathrm{w}} \cdot\left(\frac{c_{\mathrm{D}} \cdot \rho_{\mathrm{a}}}{\rho_{\mathrm{w}}}\right)^{3 / 2} \cdot U_{\mathrm{a}}^{3},
$$

where $C_{\mathrm{k}}^{*}$ : an efficiency factor for converting wind energy to TKE $(-), \rho_{\mathrm{w}}$ : the density of water $\left(\mathrm{kg} / \mathrm{m}^{3}\right), \rho_{\mathrm{a}}$ : the density of air $\left(\mathrm{kg} / \mathrm{m}^{3}\right), c_{\mathrm{D}}$ : the drag coefficient $(-)$ and $U_{\mathrm{a}}$ : the wind speed $(\mathrm{m} / \mathrm{s})$.

The annual average wind speed at Grimsel Hospitz is $U_{\mathrm{a}}=5.6 \mathrm{~m} / \mathrm{s}$. Fluid densities of $\rho_{\mathrm{w}}=995 \mathrm{~kg} / \mathrm{m}^{3}$ (water at $5.5^{\circ} \mathrm{C}$ ) and $\rho_{\mathrm{a}}=1.2 \mathrm{~kg} / \mathrm{m}^{3}$ are assumed and, according to (Anderson 2010), values of $C_{\mathrm{k}}^{*}=0.23$ and $c_{\mathrm{D}}=0.0013$ are considered. Thus, a daily mean TKE input from wind of $\eta_{\mathrm{a}}=7.9 \times 10^{-5} \mathrm{~W} / \mathrm{m}^{2}$ can be defined.

Consequently, Lake Grimsel is subjected to a TKE input due to pumped-storage operations, which is about 25 times higher than TKE naturally generated by wind. Even when comparing the artificial TKE input from maximum turbine discharge to the natural TKE input from periods with very strong wind $\left(U_{\mathrm{a}}=12.0 \mathrm{~m} / \mathrm{s}\right)$, the latter is still about 10 times lower than the TKE input from hydropower operation. The water body of the reservoir, especially near the intake and outlet structure, is affected by important mixing processes of high TKE, which were shown to weaken stratification and increase mixing frequency in pumped-storage reservoirs (Imboden 1980; Potter et al. 1982; Bonalumi et al. 2011) and which are most likely 
to slow down fine sediment settling. Thus, a potential of positively affecting the sedimentation process by in- and outflow sequences exists, as this energy could be used to disrupt settling processes in the reservoirs and to eventually evacuate suspended sediment through the power intakes or bottom outlets. However, the degree of disturbance depends on the initial hydrological, sedimentological and ecological conditions of the water body before pumpedstorage operation on the one hand, and on the layout of hydraulic inlet and outlet structures and the exploitation mode of the plant.

\section{Objective and methods}

To estimate the potential of keeping fine sediment in suspension, knowledge of flow conditions in front of intake/outlet structures during in- and outflow sequences is required. Therefore, the objective of this study was to implement a potential long-term monitoring method for flow patterns in an Alpine reservoir and record velocity profiles near the intake/outlet structure to define the impact of the hydropower operation on flow fields and to correlate flow patterns to pumped-storage activity.

Acoustic Doppler Current Profilers (ADCP) are commonly used for flow velocity measurement in rivers, lakes and estuaries and provide a non-intrusive measurement technique, that is, without disturbing the recorded flow field (Gordon et al. 1999; Cook et al. 2007). Several authors report the use of ADCP for discharge measurements or concentrations of suspended solids (Gartner 2004; Kostaschuk et al. 2005). Early long-term measurements were carried out by (Schott \& Johns 1987) who installed an upward-looking instrument in the Somali Current and recorded data for more than six months. In situ measurements are often used to calibrate numerical or mathematical models or to compare prototype results to physical modeling (Kostaschuk et al. 2005; Laval et al. 2005; Elci et al. 2007).

Velocity measurements in front of intake structures are carried out in order to either design the civil engineering works or observe and confirm their adequate functioning and their influence on the flow conditions.
Goto and Tsuchiyama (1998), Vermeyen (2002) and Dorfmann and Knoblauch (2008) used vessel-mounted ADCP to study flow fields in a reservoir, to define withdrawal for stratified and destratified reservoir conditions and to develop flushing concepts for a run-of-river power plant. Cook et al. (2007) as well as Vermeyen (2003) fixed downward-looking instruments close to power intakes to study velocities at a Kaplan turbine draft tube and provide information about flow velocities previous to conducting diving operations.

The paper introduces the study site and provides information on the ADCP measuring equipment. Then, the recorded velocity profiles in front of the intake/outlet are presented and compared to the turbine and pumping sequences of the power plant as well as to simulated flow patterns.

\section{Investigation site}

The Oberhasli region is located in the Canton of Berne, in the central Alps of Switzerland. The favorable hydrological, geological and topographical conditions in this area led to the construction of a complex system of dams, water intakes, waterways and power plants since the 1930s. Today, Kraftwerke Oberhasli AG (KWO) operates nine power plants fed by eight main reservoirs, the largest being Lakes Grimsel, Oberaar and Räterichsboden.

\section{Reservoir characteristics}

Since 1982, the Grimsel 2 pumped-storage power plant (Figure 1) is operating water from Lake Oberaar and Grimsel located at 2303 and 1909 m a.s.l., respectively. Lake Oberaar (Oa) provides an exploitable storage volume of $57 \times 10^{6} \mathrm{~m}^{3}$ and has a maximum depth of $90 \mathrm{~m}$. Lake Grimsel (Gr) has a gross storage volume of $95 \times 10^{6} \mathrm{~m}^{3}$ and a maximum depth of $100 \mathrm{~m}$. The two lakes are connected by a 5-km-long pressurized tunnel, guiding the water from the two intake/outlet structures to the power house Grimsel 2.

A volume of about $600-700 \times 10^{6} \mathrm{~m}^{3}$ of water is pumped annually from Lake Grimsel into Lake Oberaar
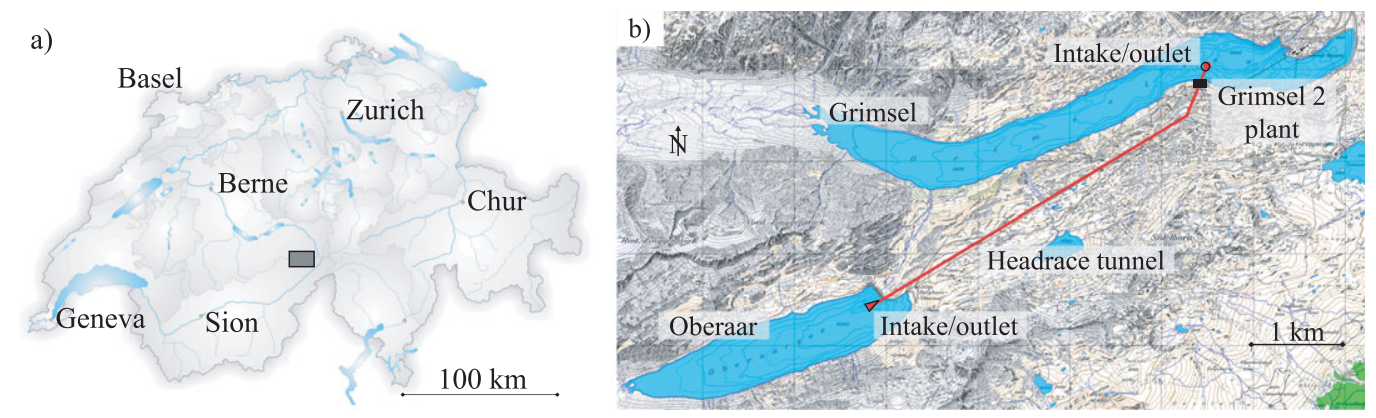

Figure 1. Location map (a, source: www.worldofmaps.net (GNU Free Documentation License)) and layout (b) of the Grimsel 2 pumped-storage scheme. 
and moved back during turbine mode. Thus, the volumes of the lower and upper reservoir are exchanged several times throughout one year of hydropower operation.

The catchment areas of the two reservoirs are partly glaciated. Denudation rate is $1-2 \mathrm{~mm} /$ year (Anselmetti et al. 2007), leading to high sediment supply, generally above $50 \mathrm{mg} / \mathrm{l}$ (Finger et al. 2006). The sediment characteristics of this 'glacier milk' in both lakes were recently investigated by Bühler and Siegenthaler (2003) and Bonalumi et al. (2011). Anselmetti et al. (2007) showed that since hydropower exploitation, approximately $85 \%$ of the annual sediment supply of $272 \mathrm{kt} / \mathrm{year}$ settles in the reservoirs, while only $40 \mathrm{kt} / \mathrm{year}$ are released downstream. Thus, slowing down sedimentation by maintaining small particles in suspension by pumped-storage operation or even downstream transfer of fine sediment by the means of power intakes or bottom outlets would be desirable to slow down the filling-up process of Lake Grimsel.

In situ measurements by Bonalumi et al. (2011) showed that the two reservoirs are ice-covered and inversely stratified in winter, with water temperatures of $T_{\mathrm{w}}=2.5^{\circ} \mathrm{C}$ along the entire water column except for the first meters below the ice, where $T_{\mathrm{w}}=0^{\circ} \mathrm{C}$. In summer, both reservoirs are ice-free and thermally stratified, with surface temperatures reaching $T_{\mathrm{w}}=14-15^{\circ} \mathrm{C}$ in the upper and $T_{\mathrm{w}}=10^{\circ} \mathrm{C}$ in the lower reservoir. In Lake Oberaar, the thermocline is located at $15 \mathrm{~m}$ depth and bottom temperature is about $T_{\mathrm{w}}=4^{\circ} \mathrm{C}$, while Lake Grimsel has no welldefined thermocline and a bottom temperature of some $T_{\mathrm{w}}=5^{\circ} \mathrm{C}$.

\section{Intake/outlet specifications}

At the foot of a 750-m-long inclined steel-lined shaft, four independent pump-turbine units are located in the Grimsel 2 underground power house and provide installed capacities in turbine and pumping mode of 348 and $363 \mathrm{MW}$, respectively. The power house is linked to the intake/outlet structure in Lake Grimsel by a pressure tunnel of diameter $D=7.50 \mathrm{~m}$. Discharges up to $Q_{\text {Turb }}=93 \mathrm{~m}^{3} / \mathrm{s}$ are injected into the reservoir during turbine mode, while during pumping mode, a maximum discharge of $Q_{\text {Pump }}=80 \mathrm{~m}^{3} / \mathrm{s}$ is withdrawn.

The Lake Grimsel intake/outlet is a submerged circular structure (Figure 2) embedded in a recess of the lake topography, with its foundation platform located at 1842 $\mathrm{m}$ a.s.l. The lateral open cylinder has an effective height $H_{i}=6.25 \mathrm{~m}$ and a diameter $D_{i}=21.70 \mathrm{~m}$. Ten guiding walls are supposed to equally distribute the out-flowing discharge on the ten sectors of the tulip. Considering the diameter and the height of the structure, the circumferential outflow section is $A_{i}=426.08 \mathrm{~m}^{2}$. However, the net in-/outflow section is reduced to $A_{i, \text { eff }}=143.58 \mathrm{~m}^{2}$ by a dense trash rack which was found to be the most effective measure to guarantee uniform flow distribution at the circumferential section (VAW 1982).

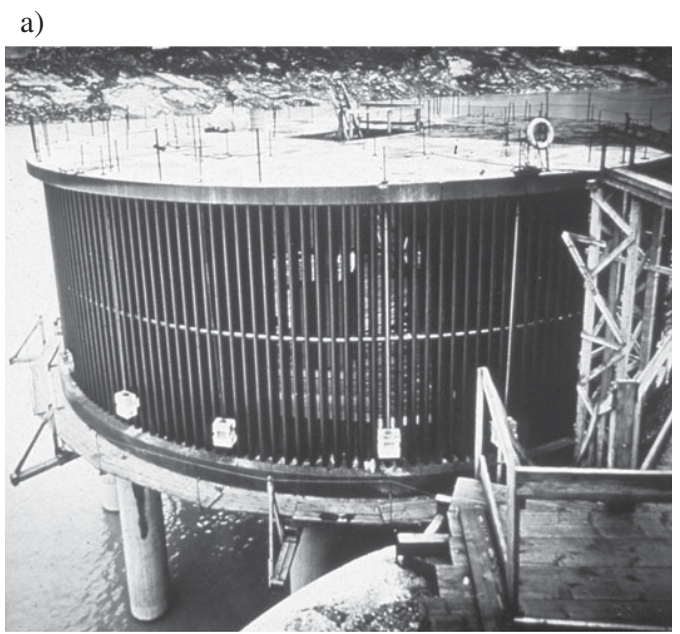

b)
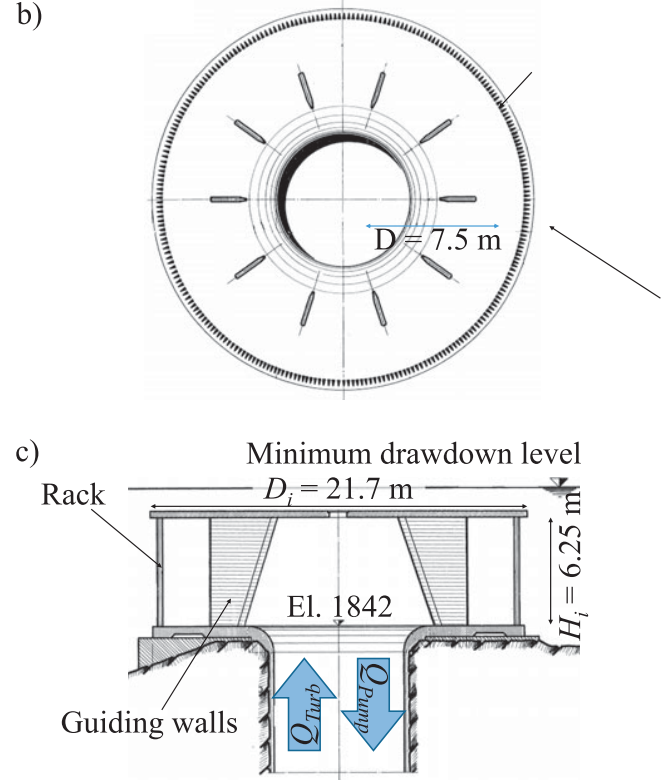

Figure 2. Grimsel 2 intake/outlet structure in Lake Grimsel; photo during construction period (a), schematic plan view (b) and cross section (c). Sources: photograph courtesy of IUB Engineering AG, with permission, and drawings from KWO, with permission.

Assuming uniform flow distribution in the net cross sections, water is injected at a speed of up to $v=2.1 \mathrm{~m} / \mathrm{s}$ at the shaft end and flow velocities are $v=0.65 \mathrm{~m} / \mathrm{s}$ through the trash rack. Minimum drawdown level of Lake Grimsel is $1850 \mathrm{~m}$ a.s.l., resulting in an intake submergence of $2 \mathrm{~m}$.

Other studies carried out on pumped-storage reservoirs have shown that a sediment-laden inflowing jet from an intake/outlet structure can be guided toward another intake or a bottom outlet. However, the potential of transferring turbid water through the reservoir depends on the intake/outlet geometry, the layout of the hydraulic works and the lake bathymetry. Whether the circumferential jet flowing into Lake Grimsel is able to reach a second power intake, the Gelmer/Grimsel 1 intake at Spittellamm Dam, 
and eventually guarantee the downstream transfer of fine sediment, remains to be seen.

\section{ADCP measurements \\ Profiler settings}

Flow velocity data were recorded by three $300 \mathrm{kHz}$ ADCP (Teledyne RDI, USA). Together with a $12 \mathrm{~V}$ lead-acid battery (Yuasa Battery Europe Ltd.), each unit was mounted on an aluminum and PVC frame, positioned on the Grimsel reservoir bottom and fixed to a mooring buoy. Dual-axis gimbals guaranteed a permanent upward-looking orientation of the instrument.

The low-frequency four beam ADCP sampled the entire water column and were operated with a bin length of $1.0 \mathrm{~m}$ and a fixed number of 85 bins, limiting the measurement error on horizontal velocity components to $\pm 12 \mathrm{~mm} / \mathrm{s}$. The mooring height of the device of $0.8 \mathrm{~m}$ and the profiler blanking distance of $2.96 \mathrm{~m}$ placed the first recording bin at $3.7 \mathrm{~m}$ above the reservoir bottom. Consequently, current profiles were registered from $3.7 \mathrm{~m}$ up to $75.0 \mathrm{~m}$ above the reservoir bottom, according to the lake level during measurement periods.

\section{Profiler position}

The three ADCP measurement lines were chosen according to the intake/outlet geometry and surrounding topography. Assuming an equally distributed discharge over the ten intake/outlet sectors (Figure 2), the measuring devices were aligned along the supposed main directions of the inflowing jets. The bathymetry of Lake Grimsel restricted the implementation possibilities for the devices, as relatively steep rock slopes surround the intake/outlet structure in the West. Eastward, in the direction of Spittellamm dam, the reservoir bottom is flat and situated almost $10 \mathrm{~m}$ below the intake level (Flotron 2006). This invert area provides most suitable conditions for velocity sampling since it guarantees a stable position of the ADCP and a maximum number of data sampling points along the water column.

Additionally, adequate locations of the profilers avoid interference between the emitted ultrasonic beam and the concrete civil engineering works or the beam of the neighboring unit. Considering the maximum sampling height of $75 \mathrm{~m}$ and the $20^{\circ}$ beam angle of the profiler, the ADCP were placed at 50, 150 and $250 \mathrm{~m}$ from the intake in the flat Eastern part of the reservoir, and at 30 and $90 \mathrm{~m}$ from the intake/outlet in the steeper Northern and Southern part (Figure 3). The closest device to the intake/outlet is named P1, the farthest P3.

During the first campaign in September 2008, the ADCP were placed on the flat part of the reservoir bottom in line with in the main geographical orientation of Lake Grimsel (E-NE). From a vessel, the ADCP were placed at the corresponding profiler positions controlled by GPS (Geko, Garmin, USA). A manual echo sounder allowed measuring the water depth to confirm the foreseen recording depth of the instrument. Positioning accuracy was $\pm 5 \mathrm{~m}$ in both East and North direction.

According to results of this first sampling period, two additional measurement lines were defined for the second campaign in November 2008, not only to better describe the influence of in- and outflow on the flow patterns in front of the intake/outlet, but also to evaluate reservoir bathymetry effects and eventual longitudinal or transversal movements of the entire lake (internal seiches). The second measurement line was orientated almost exactly $\mathrm{N}-\mathrm{S}$, the third again in the flat part, in E-SE.

Seiches are large-scale dynamics and have been investigated by (Stevens \& Lawrence 1997) for several Canadian lakes and reservoirs, as well as by Bouffard (2008) and Lemmin et al. (2005) for lake Geneva in Switzerland. Munnich et al. (1992) investigated vertical seiche modes and calculated horizontal velocities of 20 to $40 \mathrm{~mm} / \mathrm{s}$ on the bottom of the $33 \mathrm{~m}$ deep Lake Alpnach in Switzerland.
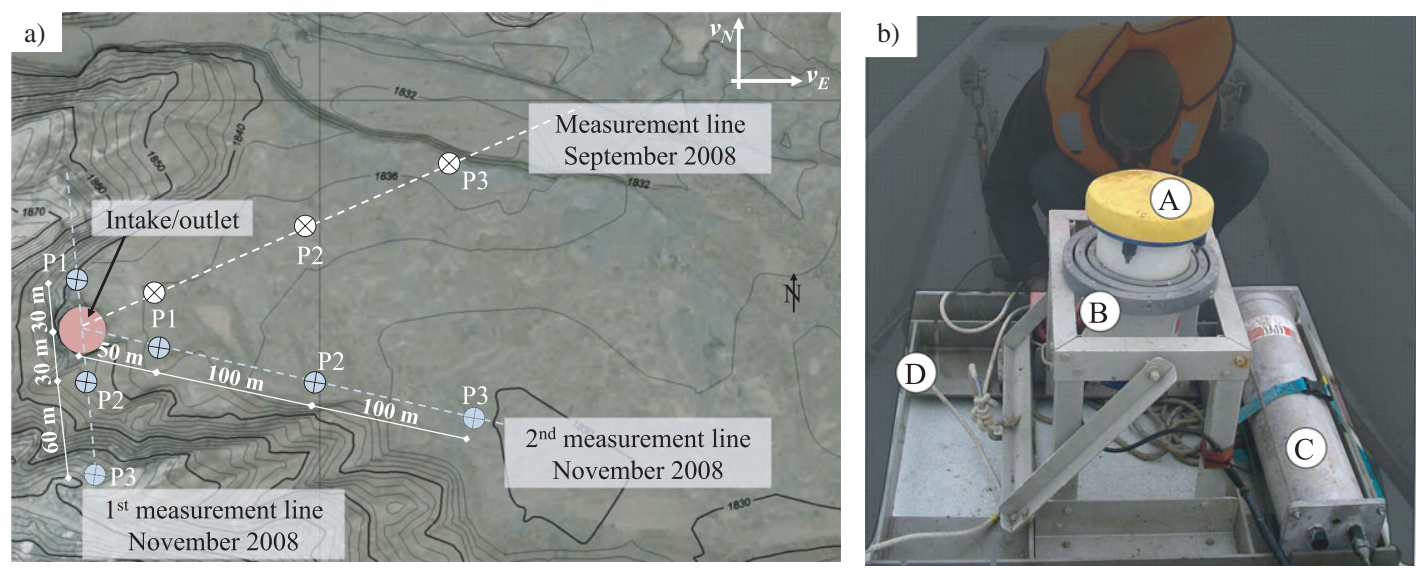

Figure 3. Lake Grimsel bathymetry and positions of the ADCP for the three measurement periods (a) and photo of the frame-mounted ADCP device (b); A is the upward-looking ADCP instrument (with protection cap); B, the dual-axis gimbals; C, the power supply and $\mathrm{D}$, the aluminum/PVC frame. 


\section{Sampling periods and raw ADCP data}

During the first in situ campaign, the ADCP data were recorded for 5 days from September 15th to 20th. In November 2008, sampling went on for two more weeks from November 6th to 20th, during which only two ADCP were operational due to technical problems of profiler P3. Pitch and roll movements were recorded, defining the moment of stabilized samplings for reliable recording periods. KWO provided Grimsel 2 operation discharges and Lake Grimsel levels for the measurement periods (Figure 4).

For September 2008, reliable data were recorded from Monday to Friday September 16th 00:00 to 19th 12:00 (called Sept). As shown in Figure 4(a), turbine sequences were predominant during this term, while pumping activity was moderate during nighttime. Three times, the plant was operated at maximum turbine discharge over 1 to $3 \mathrm{~h}$. In November, data were available from Friday November 7th 00:00 to Tuesday 11th 12:00 for the first (Nov1) and from Wednesday November 12th 00:00 to Thursday 19th 12:00 for the second measurement line (Nov2). That sampling period included main pumping sequences during the night and especially during the weekends, whereas the turbines were run at reduced capacity during most of the sequences (Figure 4(b),(c)). Consequently, flow velocities were registered for a large spectrum of in- and outflow sequences, including relatively long periods of turbine mode during weekdays and pumping mode during weekends, but also short-term alternating pumped-storage cycles.

Over the reliable sampling periods, the ADCP recorded East- and North-velocity components on the water column at a time increment of $5 \mathrm{~min}$.

Taking into account the water level in Lake Grimsel and the pressure recorded by the ADCP, the exact altitude of the devices on the reservoir bottom was determined. Data reveal that the instruments are placed slightly higher than predicted, probably due to the reservoir bottom evolution since 2006. Table 1 gives the altitude of the ADCP and the corresponding first bin of velocity recording. Except for the Nov1 campaign where ADCP were placed in the steeper surroundings of the intake/outlet, the first sampling bin is always located below the intake/outlet platform and permits to cover the entire in- and outflow section.

Raw ADCP velocity data reveal that the first 20 to $30 \mathrm{~m}$ above the instrument include reliable velocity records, before very high values start appearing up to the lake surface. These high velocities arise from insufficient suspended particles in the measuring cell to get a representative velocity average over the sampled water a)
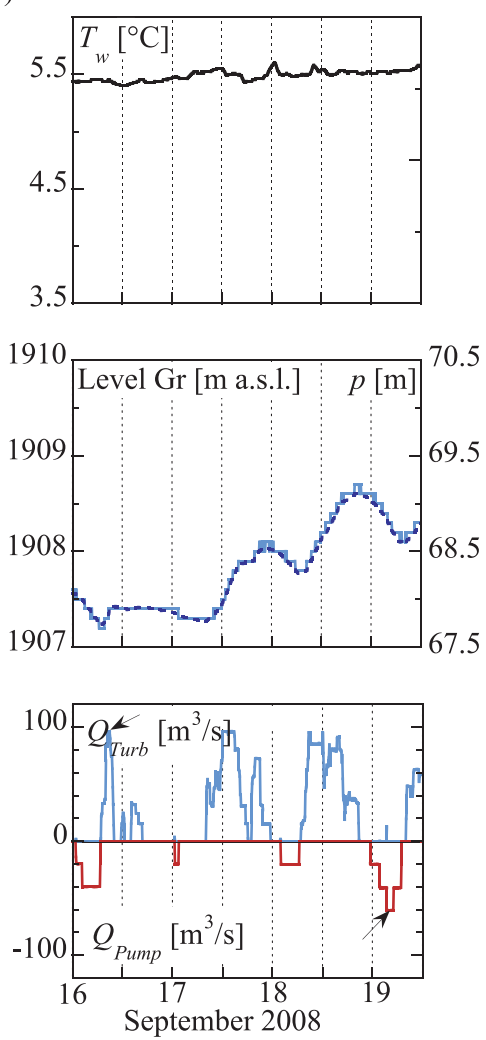

b)
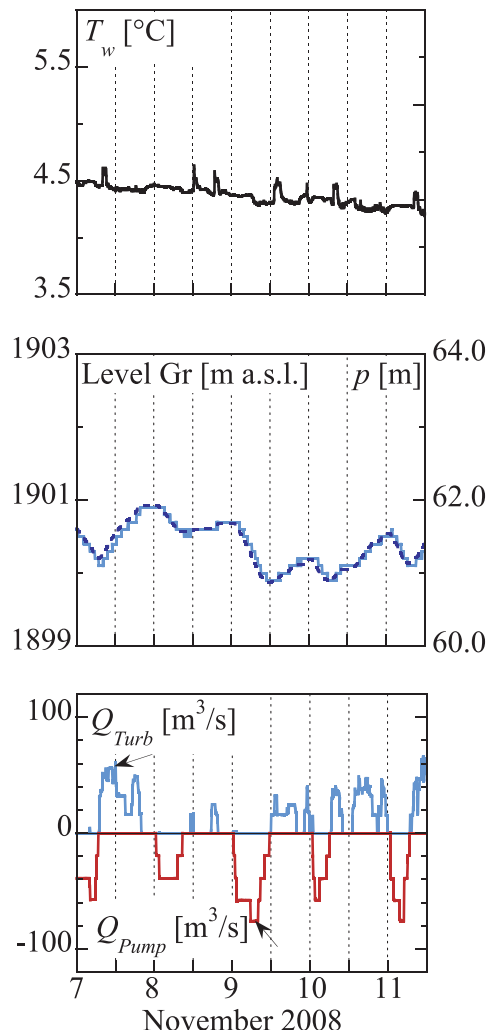

c)
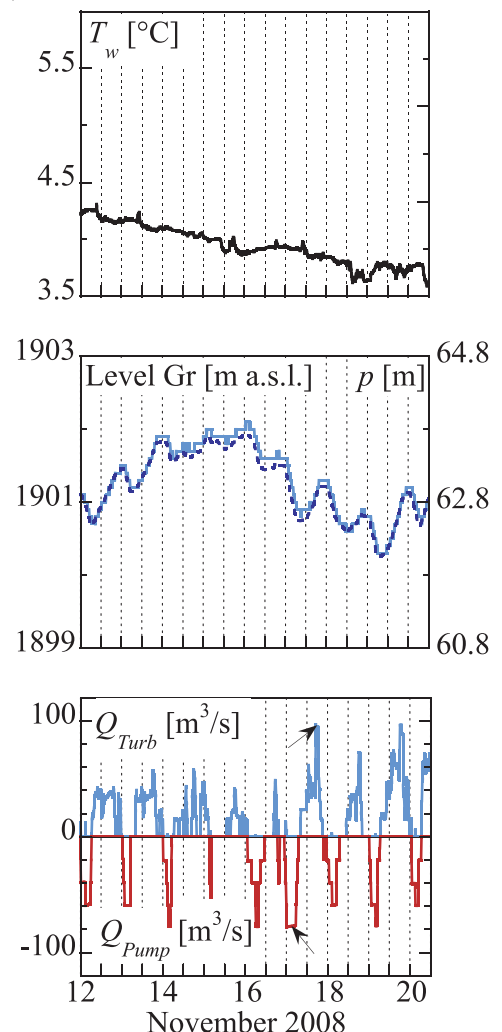

Figure 4. Temperature $T_{\mathrm{W}}$ on the reservoir bottom recorded by P1 (top), Lake Grimsel level (Gr, dashed line) and pressure p recorded by P1 (middle) and pumped-storage discharge $Q_{\text {Turb }}$, Pump of Grimsel 2 plant (bottom) during ADCP sampling periods Sept (a), Nov1 (b) and Nov2 (c). Arrows indicate the plant exploitation discharge corresponding to the presented flow patterns in Figure 11. 
Table 1. Altitude (m a.s.1.) of ADCP instruments and of the first sampling point as well as Lake Grimsel level.

\begin{tabular}{llcccr}
\hline & & P1 & P2 & P3 & Lake Grimsel level \\
\hline \multirow{2}{*}{ Sept } & Device & 1839.0 & 1840.0 & 1835.0 & $1907.2-1908.6\left(1910^{\mathrm{a}}\right)$ \\
& 1st bin & 1842.0 & 1843.0 & 1838.0 & $1899.9-1900.9\left(1900^{\mathrm{a}}\right)$ \\
\multirow{2}{*}{ Nov1 } & Device & 1839.0 & 1845.0 & 1863.0 & 1866.0 \\
& 1st bin & 1842.0 & 1848.0 & 1835.0 & $1900.3-1901.9\left(1900^{\mathrm{a}}\right)$ \\
& Device & 1838.0 & 1835.0 & 1838.0 & \\
\hline
\end{tabular}

${ }^{\mathrm{a} C}$ Constant value assumed for numerical simulations.

volume, so that standard deviation of the velocity for these cells is much larger. Thus, no reliable data were recorded over an intermediate zone of about $30 \mathrm{~m}$ until the free surface, which is clearly marked by excessive values due to a signal amplification at the water-air interface.

Temperature measured on the lake bottom remained almost constant at $T_{\mathrm{w}}=5.5^{\circ} \mathrm{C}$ in September (Figure 4(a)), with variations of $\pm 0.15^{\circ} \mathrm{C}$. During November campaigns, a continuous decrease from $T_{\mathrm{w}}=4.5$ to $3.5^{\circ} \mathrm{C}$ indicates the process toward inversely stratified reservoir conditions (Figure 4(b),(c)). Mid-term evolution of deep water temperature seems not to be affected by the pumpedstorage activity. However, some temperature peaks were recorded by the ADCP located closest to the intake/outlet structure during turbine operations and are probably related to the heat dissipation by the hydraulic machines.

\section{Meteorological data}

Wind direction and wind speed data for seiche estimations and TKE calculation were available from the weather station 'Grimsel Hospitz' located next to Spittellamm Dam, provided by the Swiss Federal Office of Meteorology and Climatology (MeteoSwiss) and the Swiss Federal Office of Energy (SFOE). As the weather station was out of order in September 2008, no data are available for the first measuring campaign. For the three weeks measuring period in November 2008, data at a time interval of 10 min was considered. Main wind direction was transversal to Lake Grimsel, direction S and S-SE, with maximum wind speed up to $U_{\mathrm{a}}=12 \mathrm{~m} / \mathrm{s}$ (Figure 5(a)). Air temperature varied from $T_{\mathrm{a}}=-5$ to $5^{\circ} \mathrm{C}$ and precipitation was limited to less than $P=1 \mathrm{~mm}$ over relatively short periods. No important rainfall or flood event is thus expected to affect flow conditions in the lake.

\section{Data processing}

As described before, ADCP records comprised two interference zones with excessively high velocities, the first originating from the loss of signal at a distance of some 20-30 $\mathrm{m}$ from the instrument and the second corresponding to the free surface of the reservoir. Obvious outliers in the time series of East or North-components a)

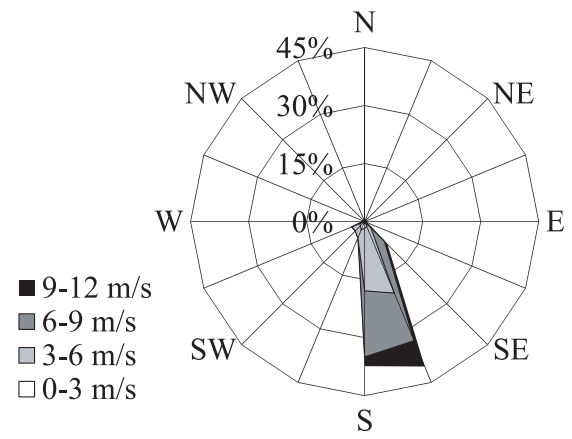

b) 7

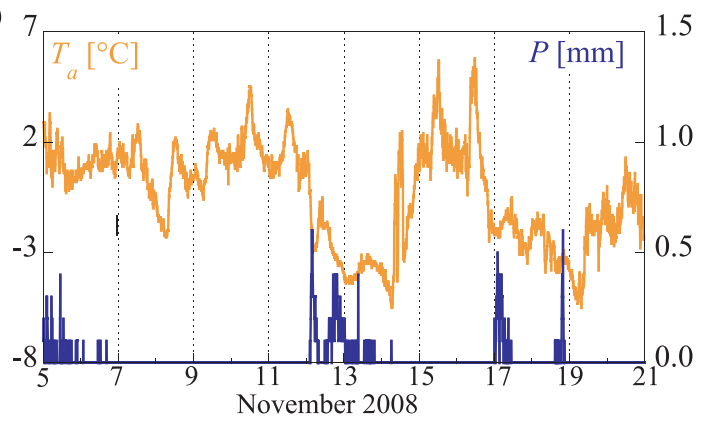

Figure 5. Wind direction and magnitude (a) and evolution of air temperature $T_{\mathrm{a}}$ and precipitation $P$ (b) for the period from 5 th November to 21st 2008 (meteorological data from MeteoSwiss, with permission).

were not considered for the illustration of flow fields as they originate from a signal loss during the measurement. This unavoidably led to gaps in the raw velocity time series, sometimes also in the interesting zone of measurements. Consequently, average velocity resultants were calculated over five time steps, slightly smoothing the profile by a centered moving average but allowing keeping the information on the dynamic processes in front of the intake/outlet.

A detailed analysis of the velocity time series included a comparison between power spectra of ADCP data series and discharge data from the plant operator to correlate velocities and pumped-storage operations. Based on the Fast Fourier Transform, this approach is often used in signal processing and allows relating the power of a signal to its corresponding frequency (Lyons 2004). A rectangular windowing function was applied for calculation, and raw ADCP data were used to separately study the E- and 
$\mathrm{N}$-velocity components. However, only the first 20 cells above the reservoir bottom are considered hereafter, as with increasing distance from the measuring device, the spectra of the velocity signal becomes strongly affected by noise.

\section{Numerical modeling}

The flow conditions corresponding to the three measurement periods in Lake Grimsel were simulated numerically in a 3D ANSYS-CFD model and the corresponding CFX solver to study the influence of bathymetrical conditions on the jet direction and backflow zones in the reservoir. Three basic scenarios were studied, corresponding to the three in situ measurement periods (Sept, Nov1 and Nov2; Table 1). Additional simulations were carried out on the first turbine sequence of the September scenario to study the sensitivity to temperature differences between the injected and the resident water.

\section{Geometry and meshing}

Based on topographical data recorded during a reservoir drawdown in 2006 (Flotron 2006) the lake geometry of equidistant contour lines of $10 \mathrm{~m}$ between 1830 and $1910 \mathrm{~m}$ a.s.l. was defined. The model represented $60 \%$ of the total Lake Grimsel volume, ending some $1000 \mathrm{~m}$ upstream of the intake/outlet location, as this part of the reservoir was considered of negligible influence on the flow patterns in the study area. The vertical connection between intake/outlet and shaft was reproduced with a length of $5 \mathrm{~m}$.

The edge length of the unstructured tetrahedral meshing elements was set to $5 \mathrm{~m}$ in the surroundings of the intake/outlet structure and the entire reservoir volume from 1830 to $1860 \mathrm{~m}$ a.s.l. From there and up to the lake surface, the elements started growing at a rate of 1.2, but the edge length of all elements was systematically smaller than $20 \mathrm{~m}$. Boundaries were meshed with a maximum edge length of $1 \mathrm{~m}$ except for the shaft section and the intake body on which $0.5 \mathrm{~m}$ were imposed. These settings lead to a computational mesh composed by 1.4 million cells.

\section{Boundary conditions, simulation controls and model validation}

The main assumption regarding boundary conditions concerns a constant reservoir level at 1910 and $1900 \mathrm{~m}$ a.s.l., respectively for the simulation of Sept and Nov1 \& 2 scenarios. Prototype-level variations during the three measurement periods were limited to only $\pm 2.0 \mathrm{~m}$. As the model works at constant water level, continuity was assured by an artificial withdrawal or injection of water at the up- and downstream end of the model. Upstream, water is provided through a 10 -m-thick layer at the surface and over the entire reservoir width. Downstream, a virtual 10 -m-high spillway opening over the total width of Seeuferegg dam allows evacuating water during turbine mode. The reservoir bottom and the two dams were simulated as no-slip boundaries $(v=0)$ while at the lake surface free-slip conditions were applied. The model of Lake Grimsel and the corresponding boundary conditions are illustrated in Figure 6.

The effect of Coriolis force is not included in the model. The authors consider that the deviation due to earth rotation can be neglected especially as we encounter bathymetric lateral confinement near the intake/outlet structure by the valley flanks and bottom. In that case, the influence of the geometry becomes dominant.

On the lake bottom and along concrete works such as walls and the top cover of the intake/outlet structure, flow velocities were also imposed to zero. An in- or outlet boundary condition was set at the end of the vertical conduit, leading the water into or out of the reservoir.
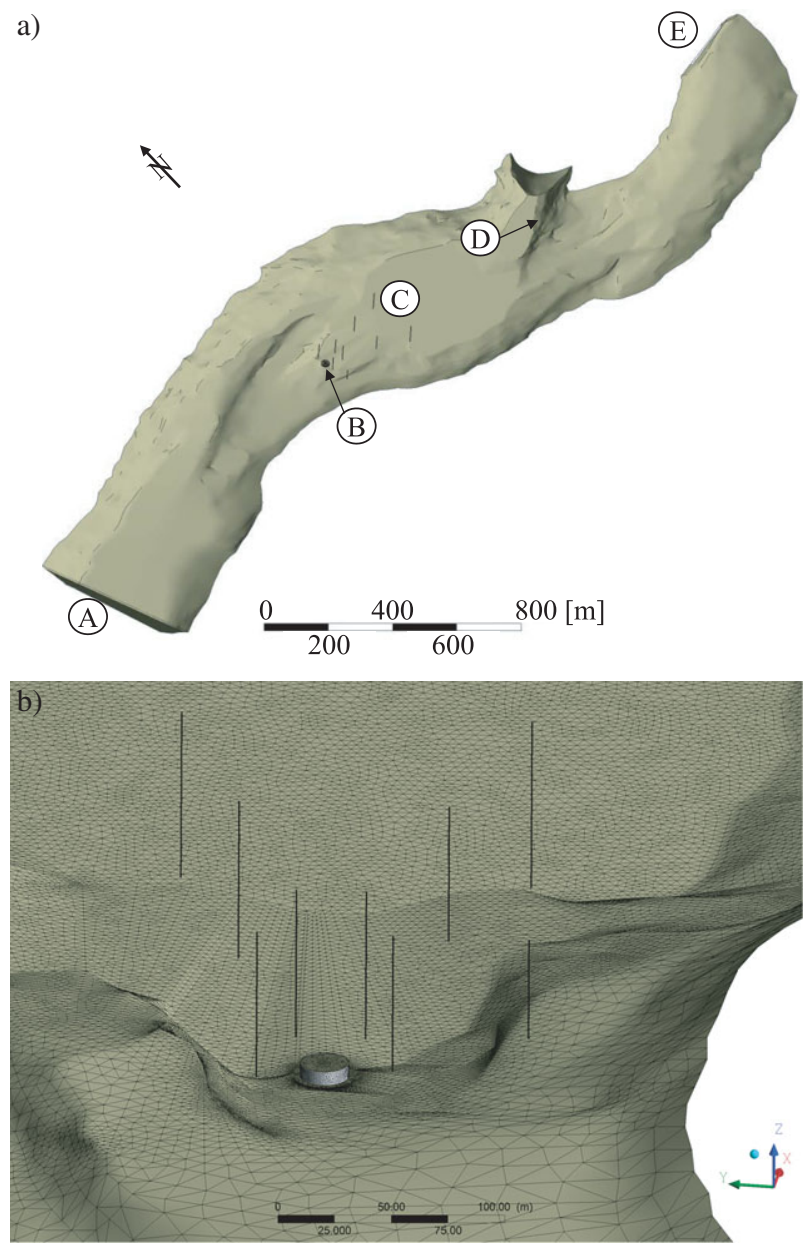

Figure 6. Numerical model (ANSYS-CFD) of Lake Grimsel (a) and detail of the calculation mesh around the intake structure (b), A is the upstream boundary condition (inlet); B, the Grimsel 2 intake structure (inlet/outlet); C, the nine vertical profiles corresponding to the ADCP positions around the intake/outlet structure; D, the Gelmer/Grimsel 1 intake (outlet) and E, the downstream boundary condition (outlet, Seeuferegg Dam with implemented spillway crest). 
Simulation control comprised a transient analysis with adaptive calculation time steps, applying a $k-\varepsilon$ turbulence model. The model solved the corresponding differential equations applying the second-order backward Euler method. Simulation time steps were adapted from $t=1$ to $10 \mathrm{~s}$ according to the root mean squareconvergence criteria of a residual target of 0.0001 . Transient results were registered every $5 \mathrm{~min}$, respecting the sampling frequency of the in situ measuring devices.

The lake volume was defined as continuous, nonbuoyant and isothermal fluid (clear water), respecting water characteristics at a temperature of $T_{\mathrm{w}}=5.5^{\circ} \mathrm{C}$. However, differences in sediment concentration or temperature between the two lakes might affect flow patterns in front of the intake/outlet, especially during generating mode, when density differences between resident and inflowing water lead to jet stratification. To approach such

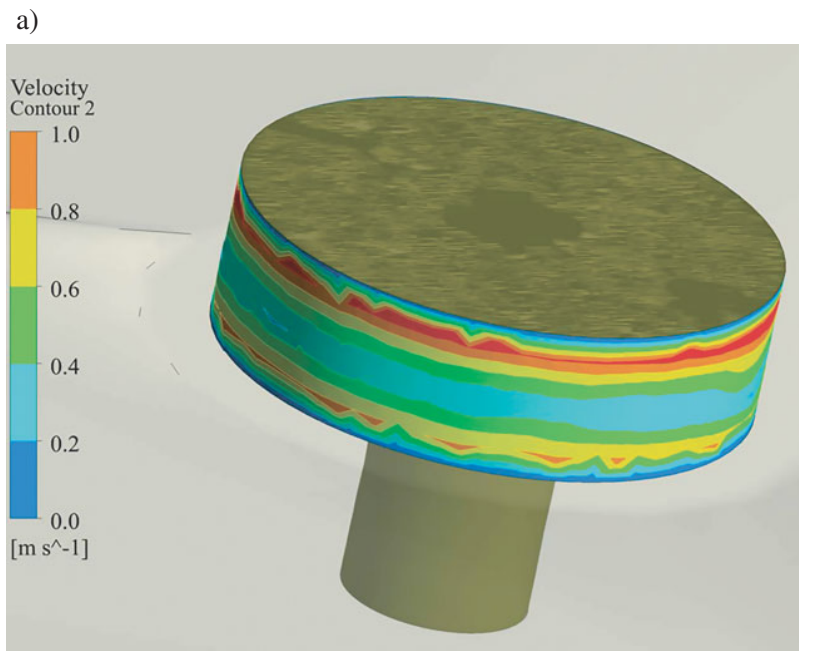

b)

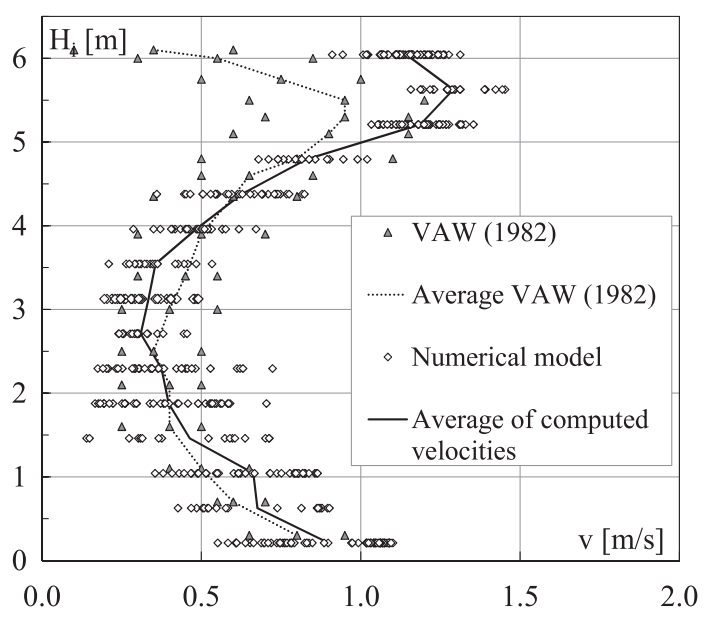

Figure 7. Computed flow velocities at the trash rack of the Grimsel 2 intake/outlet structure for turbine operation at $Q_{\text {Turb }}=90 \mathrm{~m}^{3} / \mathrm{s}$; numerically computed velocity map around the intake/outlet section of the structure (a) and comparison of flow velocities $\mathrm{v}$ at different levels $\mathrm{H}_{\mathrm{i}}$ of the intake/outlet section (b) found experimentally in a physical model (VAW 1982) and computed by the numerical model. behavior, two additional scenarios simulate flow fields when warmer or colder water from the upper reservoir is injected into Lake Grimsel. Temperature differences of $\Delta T_{\mathrm{w}}= \pm 0.5^{\circ} \mathrm{C}$ were admitted in these cases, based on the ADCP observations.

The correct behavior and the reliability of the numerical model were evaluated based on the velocity distribution at the trash rack of the intake/outlet structure, which had been tested in a physical model prior to the construction of the pumped-storage plant (VAW 1982). The numerical model slightly overestimates flow velocities in the upper part of the intake/outlet section between $H_{\mathrm{i}}=5$ to $6 \mathrm{~m}$ but otherwise reproduces very well the behavior found experimentally (Figure 7). It can thus be considered well adapted for the analysis of flow phenomena in Lake Grimsel.

\section{Results and discussion}

The ADCP recorded velocity components in East $v_{\mathrm{E}}$ and North direction $v_{\mathrm{N}}$, indicated in Figure 3(a). Three aspects of flow patterns were analyzed based on the flow velocity data extracted from the measuring devices. First, the main frequencies of the velocity time series were compared to those of the discharge series to correlate flow patterns recorded to the pumped-storage operation of the plant. Second, the main flow directions both measured in situ and calculated numerically were studied and opposed. Finally, a quantitative analysis was driven to compare flow velocities recorded by the ADCP to the values calculated by the numerical model.

On the one hand, the qualitative and quantitative analysis of flow patterns is supported by 1D flow profiles, which represent velocities in the planes built by the ADCP, that is, resultants projected on the measurement lines. On the other hand, 2D velocity vectors were plotted along the water column above the measurement locations.

In numerical simulations, all nine ADCP positions were analyzed for the three different in situ measurement periods. The model identified the main influences of topography on the flow fields and recirculation cells and provided order of magnitude data regarding flow velocities and temporal response of flow patterns. Simulated velocity profiles cover the entire water column, from the very bottom to the free surface. Some of the information retrieved from the numerical model was thus complementary to the in situ measurements, especially the behavior of flow patterns in the near-bottom zone and in intermediate depths which lacked accurate in situ sampling.

\section{Correlation between flow velocities and operation discharge}

Plant operation discharge signal is characterized by three main peaks, at frequencies of $f=0.3 \times 10^{-5}, 1 \times 10^{-5}$ and $2.2 \times 10^{-5} \mathrm{~Hz}$ corresponding to periods $1 / f$ of 
approximately 96, 24 and $12 \mathrm{~h}$ (Figure 8). These frequencies are present for all three measurement terms, whereas Sept scenario has a slightly higher magnitude.

Generally, velocity spectra flatten out into noise spectra at frequencies around $f=4 \times 10^{-5} \mathrm{~Hz}$. Data sets recorded further away from the device present more fluctuations and do not show distinct peaks (gray lines in Figures 8 and 9). The signals of the first recording cells show the interaction between the temporal evolution of velocity profiles and pumped-storage operation.

For P1 and P2 of the Sept measurement line, the Ecomponent shows a clear response to the three main peaks of discharge with a main frequency of $f=1 \times 10^{-5} \mathrm{~Hz}$ or a period of about $24 \mathrm{~h}$. The signal of N-components is more scattered and distinct peaks are absent. At P3, E-velocities present similar behavior, but a response of $\mathrm{N}$ components close to the bottom is observed at a frequency of $f=0.3 \times 10^{-5} \mathrm{~Hz}$ or a period of some $96 \mathrm{~h}$.

The velocity spectra of data recorded in Nov1 line presents different characteristics. P1 and P2 both reveal a correlation between pumped-storage cycles and $\mathrm{N}$ velocity component (Figure 9(b), above). Additionally, an important peak amplitude of E-velocity component is observed at P2 at a frequency of $f=1 \times 10^{-5} \mathrm{~Hz}$ (period 1/f about $24 \mathrm{~h}$ ) for the bins 2 to 6 , confirming the redirection of the flow toward the East of the intake/outlet.

Nov2 line in the invert is again presenting a strong correlation between discharge and $E$-velocity components, with higher amplitudes than observed at the same distance from the intake in September (Figure 9, below). Again, both velocity components have a main frequency of $f=1 \times 10^{-5} \mathrm{~Hz}$ (period $1 / f$ about $24 \mathrm{~h}$ ), the predominant frequency for all measured profiles.

Seiche periods in longitudinal and transversal directions of Lake Grimsel were computed considering a lake length of $6 \mathrm{~km}$ and a width of $500 \mathrm{~m}$, as well as depth ranges from $37 \mathrm{~m}$ to $100 \mathrm{~m}$. Thus, longitudinal seiches would result in frequencies from $f_{\mathrm{L}}=1.6$ to $2.6 \times 10^{-3} \mathrm{~Hz}$ corresponding to a period of some 6 to $10 \mathrm{~min}$ and transversal ones from $f_{\mathrm{T}}=1.9$ to $3.1 \times 10^{-2} \mathrm{~Hz}$ (0.5 to $\left.1 \mathrm{~min}\right)$. As peaks in this frequency range are not observed for the recorded velocity signals, it is assumed that no significant internal oscillation was altering the flow field measurements. a)


b)


Figure 8. Power spectra for discharge $Q$ and velocity components $v_{\mathrm{E}, \mathrm{N}}$ at P1 (top), P2 (middle) and P3 (bottom) for the Sept measurement line; E-velocity components (a) and N-velocity components (b). Discharge spectrum is represented by the blue line, velocity spectra at $5 \mathrm{~m}$ (continuous), $10 \mathrm{~m}$ (dashed) and $20 \mathrm{~m}$ (dotted) above the reservoir bottom are represented by black lines. 
a)
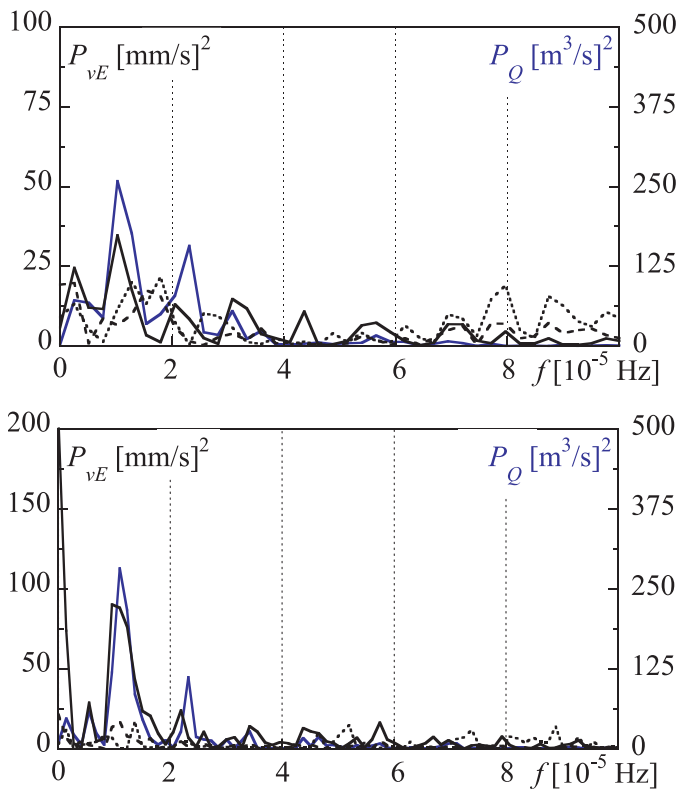

b)


Figure 9. Power spectra for discharge $Q$ and velocity components $v_{\mathrm{E}, \mathrm{N}}$ for Nov1 (above) and Nov2 measurement lines (below); E-velocity components (a) and N-velocity components (b) at P1. Discharge spectrum is represented by the blue line, velocity spectra at $5 \mathrm{~m}$ (continuous), $10 \mathrm{~m}$ (dashed) and $20 \mathrm{~m}$ (dotted) above the reservoir bottom are represented by black lines.

\section{Main flow directions in the vicinity of the intake/outlet structure}

Figure 10 presents typical axial flow velocity profiles for pumping and turbine sequences during campaigns Sept and Nov1 and reveals the already-mentioned non-valid sampling zones near the surface and in the mid-water body. 1D profiles show that only the profiles close to the intake are affected when water is pumped out of the reservoir.

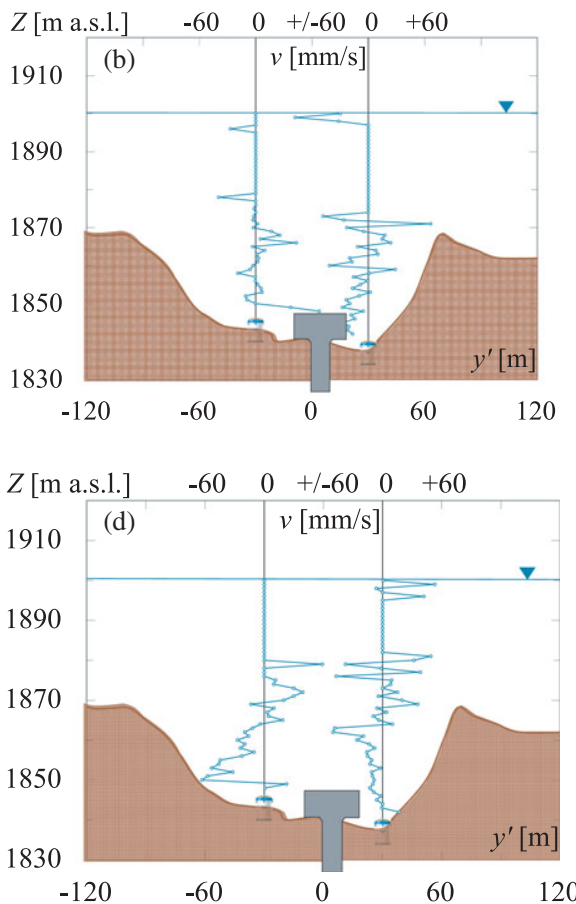

Figure 10. Typical flow velocities v recorded by the three ADCP, projected on the measurement lines for periods of pumping (outflow, a) and turbine (inflow, c) for the Sept scenario and for pumping (b) and turbine mode (d) for the Nov1 Scenario. 
P2 and P3 on the Sept line do not clearly show the influence of the pumping operations and present non-structured fluctuations.

In the flat part of the reservoir (W-E), only small axial velocities are measured, indicating that either velocities are low in this area, or not oriented in the measurement plane.

During turbine sequences (inflow), globally higher axial velocities are measured than during pumping mode. Some $5 \mathrm{~m}$ above the reservoir bottom the Sept line flow directions at P1 and P2 start pointing toward the intake/outlet most of the time, revealing a backflow phenomenon in front of the intake structure (Figure 10(c)). Only P3 in the flat reservoir part indicates velocity vectors pointing away from the intake/outlet. This observation confirms the well-known flow field caused by a jet issuing into a reservoir such as during hydropower operation as well as industrial applications. For the Nov2 line, which is located in the flat part of the reservoir bottom as well, similar behavior was observed, with backflow zones about $5 \mathrm{~m}$ above the bottom. However, flow directions pointing away from the structure are more frequent.

The Nov1 line reveals that flow to the North of the intake (profile on the right of the intake/outlet in Figure 10(b)) is not primarily orientated in the intakeADCP direction. Apparently, flow is deviated quickly after expulsion in the zone close to the steep rock slope. To the
South, where the slope is less steep, velocity profiles show a clear tendency away from the intake/outlet.

To get additional information about the main orientation of velocity vectors, plots including $2 \mathrm{D}$ velocity profiles along the water column three-dimensional plots were established and presented in Figure 11. As discussed for axial velocities, inflowing water is mainly directed toward E-SE (corresponding to the Nov2 measurement line, Figure 11(e)), indicating the presence of a largescale circulation cell developing due to the confining topography.

During pumping mode, main influence is observed at the profile to the North of the intake, probably amplified by the recirculation cell in the reservoir, which starts rotating counterclockwise during turbine mode and continues turning even after stopping the power generation.

The deep zone of the water body is agitated continuously and moves not only when pumps or turbines are working, but also during periods with no in- or outflow from the power plant.

Numerical results show very low effect of pumping operation (withdrawal) at Grimsel 2 intake on the surrounding water body. Only at the closest profilers, some low velocities are observed. Otherwise the developed flow field around the structure is not generating measurable velocity vectors in the numerical model.
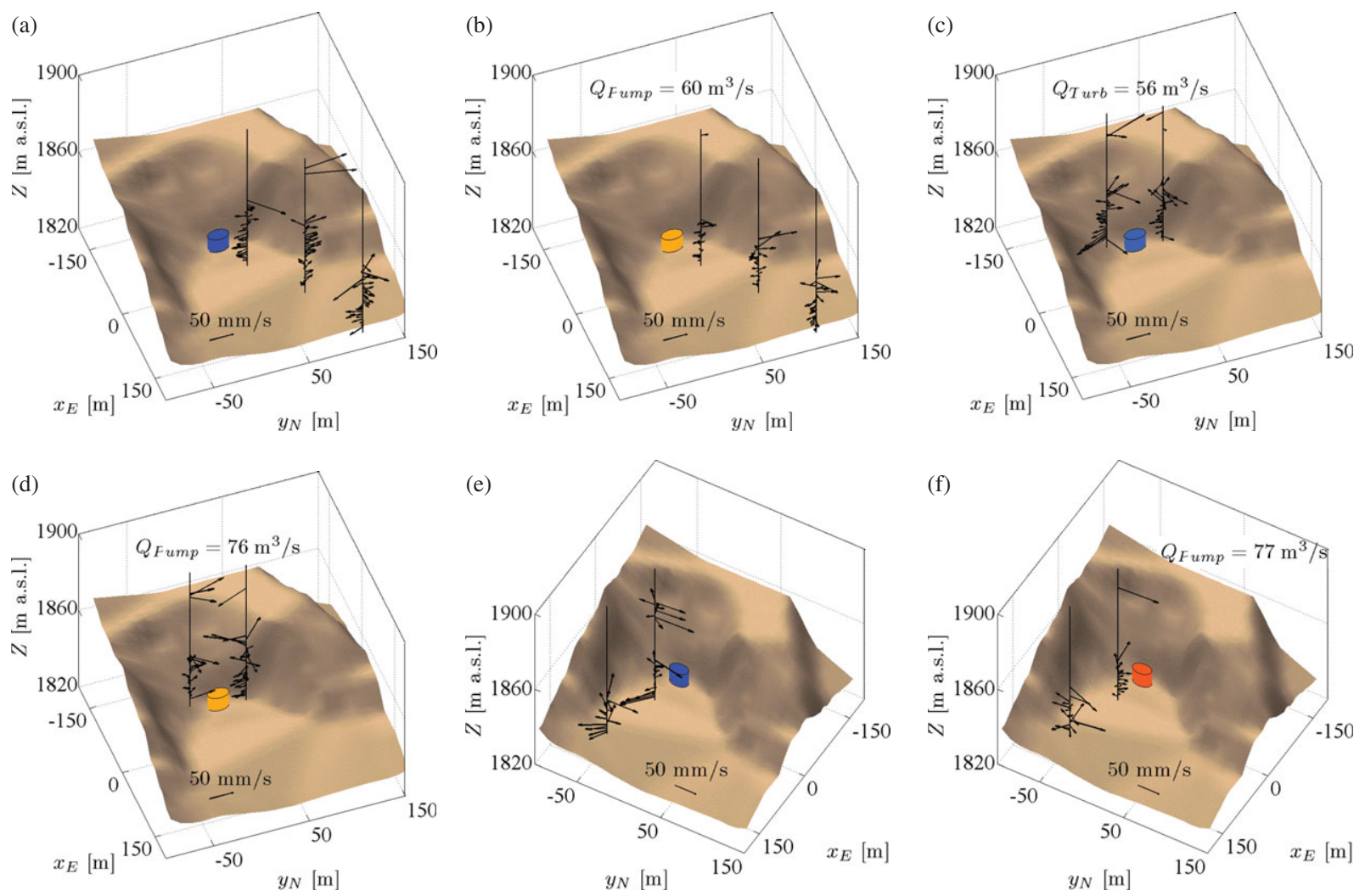

Figure 11. 2-D-velocity profiles near the Grimsel 2 intake/outlet structure during turbine (inflow, left) and pumping modes (outflow, right); September 17th 13:20 h (a), September 19th 05:00 h (b), November 07th 10:30 h (c) and November 9th 07:30 h (d), November 17 th $18: 20 \mathrm{~h}$ (e) and $02: 10 \mathrm{~h}$ (f). For the discharge data corresponding to the illustrated flow patterns, please refer to Figure 4. 
Turbine mode creates characteristic flow patterns with a circumferential inflow from the intake/outlet section on the lowest 5 to $7 \mathrm{~m}$ of the water column. Above this jet area, a strong backflow zone develops toward the outlet (Figure 12). These main characteristics correspond to results of in situ flow patterns. However, the model presents a higher consistency of flow profiles in time, with less temporal fluctuation of velocity vectors.

The velocity vectors on the reservoir bottom are slightly oscillating but keeping their main direction. In contrast to the 2D ADCP flow fields, the Nov2 line is less influenced by the inflowing jet, especially P2 seems to be placed in a sheltered zone of almost no velocities. In fact, during the entire simulation time, the vertical velocity profile at this location remains unaffected by the inflowing water.

The measured profiles at P1 and P2 in the Nov1 line are very well reproduced by the numerical model, emphasizing the complexity and instability of the flow fields in front of the Grimsel 2 intake/outlet. Overall, the main flow directions and backflow zones computed in the numerical model correspond well to what has been measured during the in situ campaigns.

\section{Flow velocities around the intake/outlet structure}

Results from the ADCP measurements in September reveal that during pumping operation, maximum axial velocity of $v=60 \mathrm{~mm} / \mathrm{s}$ is reached in N-S direction at $y^{\prime}=30 \mathrm{~m}$ from the intake, with an alteration of the water column corresponding to the intake height, approximately (Figure 10(a)). At $x^{\prime}=50 \mathrm{~m}$ to the East of the structure, in the flat reservoir part, only some $v=20 \mathrm{~mm} / \mathrm{s}$ were recorded. The backflow zone during turbine sequences presents axial velocities up to $v=50 \mathrm{~mm} / \mathrm{s}$ (Figure 10(c)). For the Sept measurement line, only P3 in the flat reservoir part indicates velocity vectors pointing away from the intake/outlet with $v=30$ to $50 \mathrm{~mm} / \mathrm{s}$ during turbine operation.

When water enters the reservoir, Nov1 line is characterized by the flow deviation to the North and velocity profiles pointing away from the structure to the South, which presents relatively high velocities around $v=70$ to $80 \mathrm{~mm} / \mathrm{s}$ (Figure $10(\mathrm{~b})$ ).

Highest absolute velocities up to $v=120 \mathrm{~mm} / \mathrm{s}$ are observed close to the intake/outlet, as well as at both profilers in the main flow direction (E-SE, Nov2, Figure 11(e)). The few still very high velocity vectors located at the limit toward the blind zone and the water-air interface are not taken into account. In the backflow zones, mean velocity is calculated at $v_{m}=30$ to $40 \mathrm{~mm} / \mathrm{s}$.

These velocity magnitudes can be compared to the computations carried out by the numerical model. However, evaluation of the temporal evolution of flow patterns, especially during turbine mode, could not be clearly stated based on the ADCP measurements. The numerical model allows systematic estimation of flow development and average flow velocities could be calculated for the reaches between the profiler locations. When turbines are started after pumping or no operation, the flow injected into Lake Grimsel reaches the two N-S profilers (Nov1) located $30 \mathrm{~m}$ from the intake/outlet after $t=5$ to $10 \mathrm{~min}$. The first profilers in the invert at $50 \mathrm{~m}$ (Sept and Nov2) is reached after $t=10$ to $20 \mathrm{~min}$, depending on discharge. This corresponds to mean jet velocities of $v=40$ to $100 \mathrm{~mm} / \mathrm{s}$. The
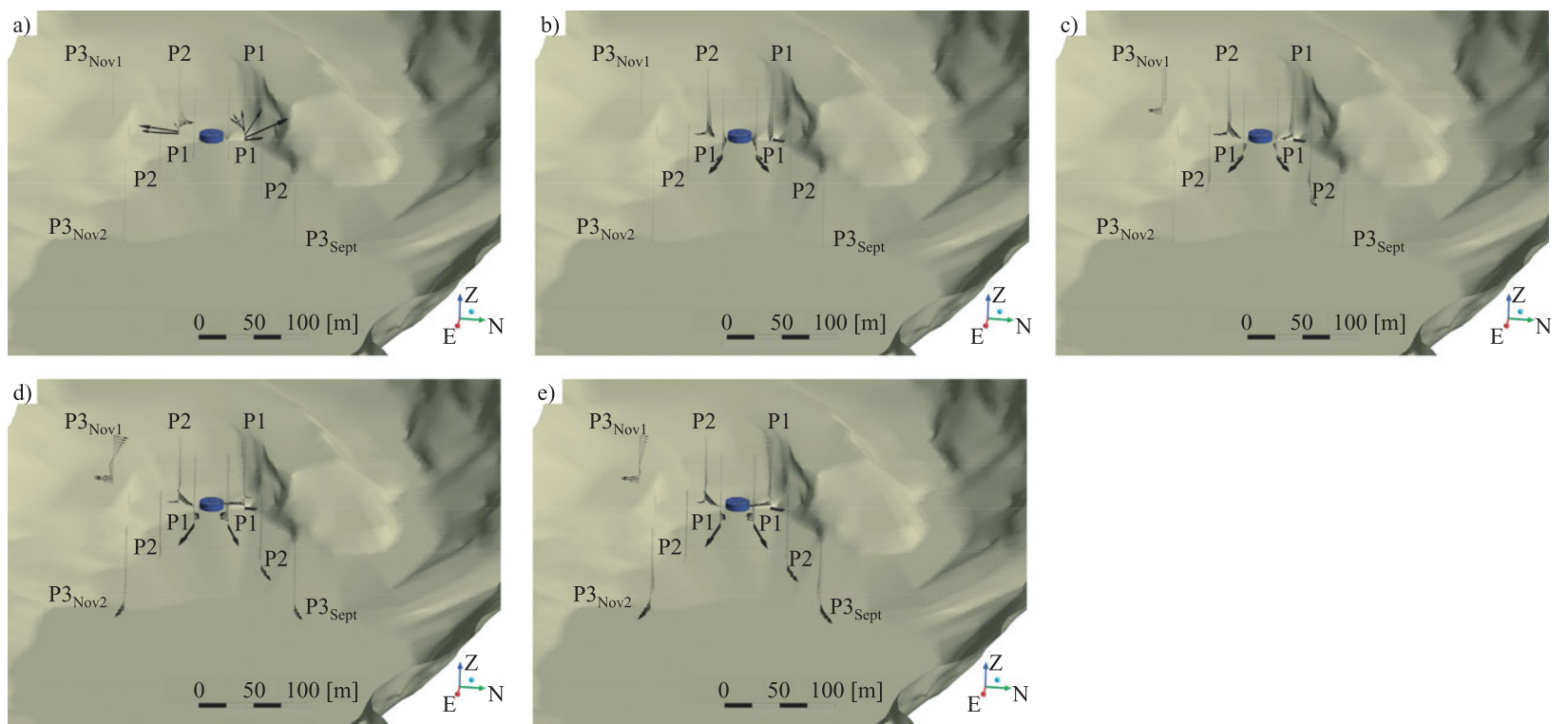

Figure 12. Development and magnitude of computed flow patterns around Grimsel 2 intake/outlet during turbine mode (inflow); $t=10$ (a), 20 (b), 70 (c), 110 (d) and 140 min (e) after the beginning of the turbine sequence on September 16th 2008 07:00 h. 
response time between profilers is $t=30$ to $65 \mathrm{~min}$ from $\mathrm{P} 1$ to $\mathrm{P} 2$ and $t=45$ to $75 \mathrm{~min}$ from $\mathrm{P} 2$ to $\mathrm{P} 3$ with corresponding flow velocities of $v=20$ to $50 \mathrm{~mm} / \mathrm{s}$. These orders of magnitude correspond to the values measured in prototype both for the near structure zone and for the measurement locations farther away from the intake/outlet. Steady flow fields were observed only after 150 minutes of continuous turbine operation. The temporal development of velocity profiles computed numerically for a turbine sequence starting on September 16th 2008 is illustrated in Figure 12.

The mentioned velocities are valuable for jet propagation in nearly calm water conditions in the lake, that is, when the water body flow is not moving any more after pumping sequences or no operation periods. However, the developed jet, which is continuously fed by water from the intake/outlet, can reach higher velocities. At P1, up to $v=200 \mathrm{~mm} / \mathrm{s}$ are computed in the model and at $\mathrm{P} 2$ and $\mathrm{P} 3$, and computed flow velocities reach $v=80$ to $100 \mathrm{~mm} / \mathrm{s}$.

The flow connection between the Grimsel 2 and Gelmer/Grimsel 1 intakes is established only after more than $9 \mathrm{~h}$ of continuous turbine operation at Grimsel 2 (Figure 13). The circumferentially inflow is not creating a well-oriented jet and velocities decrease quickly with increasing distance from the intake/outlet. Thus, using the two plants for suspended sediment transfer from Lake Oberaar through Lake Grimsel into Lake Räterichsboden is not a feasible measure.

According to results of the two additional scenarios, based on the first $3 \mathrm{~h}$ of turbine mode on September 16th, a temperature difference of $\Delta T_{\mathrm{w}}= \pm 0.5^{\circ} \mathrm{C}$ between inflowing and resident water does not fundamentally change the flow patterns in Lake Grimsel. Due to relatively low-density differences for the simulations, buoyancy effects remain small and do not change the distribution of the inflowing jet. However, if fluid properties

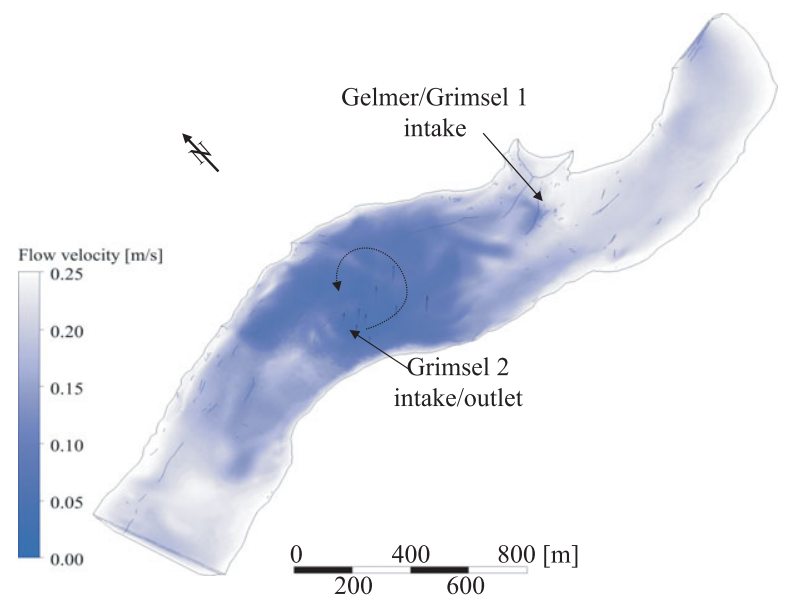

Figure 13. Volumetric distribution of flow velocity after $t=9 \mathrm{~h}$ of turbine mode on September 18th. The large-scale recirculation cell is indicated by the dashed arrow. Only the near structure zone of the reservoir is agitated. diverged more, for example, in the case of sediment-laden water injected into less-turbid water, buoyancy effects would probably affect the jet trajectory considerably and change the flow fields near the intake/outlet structure.

\section{Conclusions}

In pumped-storage schemes, the thermal stratification and nutrient content of the water body in the areas close to the intake/outlet structure is known to be altered by hydropower exploitation and sediment may sometimes be resuspended and entrained. Keeping in suspension or even remobilization of fine sediment could be an interesting reservoir management strategy if the sedimentation and filling-up processes represent an operational or structural safety problem. To highlight the reservoir areas susceptible to sedimentation and those, which could possibly be cleaned as they are subjected to high turbulence, knowledge on flow velocities and directions are required. In Lake Grimsel, the lower reservoir of the Grimsel 2 pumpedstorage scheme in the Swiss Alps, the calculated artificial TKE input due to hydropower operation is about 25 times higher than energy naturally generated by wind. Therefore, it potentially presents the possibility to slow down fine sediment settling by the means of plant exploitation. To investigate how in- and outflow sequences influence flow patterns in a pumped-storage reservoir, Lake Grimsel was equipped with three ADCP which continuously sampled flow velocities along the water column in front of the intake/outlet structure.

Frequency analysis of the recorded velocity signal indicates correlation between the sampled flow patterns and the pumped-storage activity. The predominant period of the velocity time series is $1 / f=24 \mathrm{~h}$, corresponding to the daily pumped-storage cycles of the plant. Seiche frequencies were not discovered in the velocity spectra.

$1-\mathrm{D}$ and 2-D velocity profiles along the water column established based on the in situ data reveal that pumping (withdrawal from the reservoir) only affects the water body close to the intake while turbine mode (inflow into the reservoir) generates relatively high flow velocities perceptible even at some $150 \mathrm{~m}$ from the outlet.

Combined with numerical modeling, prototype flow velocity measurements in the intake/outlet area of a reservoir combined with numerical modeling allows detection of main flow directions and backflow zones in a reservoir, quantification of flow velocities in the surroundings of the intake/outlet and evaluation of temporal response of the water body to in- and outflow sequences. Due to the autonomous power supply, the ADCP provide an adequate mid-term monitoring system.

Pumped-storage activities have a measurable impact on reservoir dynamics, as shown for the case of Lake Grimsel. Especially water ejected into the reservoir induces large eddy flow fields in the reservoir, depending on lake 
topography and operated discharge. Compared to naturalwind-induced kinetic energy input, hydropower operation can become the driver parameter governing flow dynamics in a storage volume. It could thus be specifically applied for mixing the water in the vicinity of an intake/outlet structure, for example after the arrival of a turbidity current, and thus slow down or even hinder fine sediment settling. As flow patterns, turbulence, sediment settling and lake stratification are related, flow monitoring in combination with numerical modeling is a crucial step toward a sustainable reservoir management.

\section{Disclosure statement}

No potential conflict of interest was reported by the authors.

\section{Funding}

This work was supported by Swiss Federal Office of Energy, swisselectric Research and HydroNet Project Consortium Funded by the Competence Center Energy and Mobility (CCEM).

\section{Notes on contributors}

Dr Michael Müller graduated in Civil Engineering from the École Polytechnique Fédérale de Lausanne (EPFL), Switzerland, in 2007. From 2005 to 2006 he studied at the Universidad Politechnica de Valencia (UPV), Spain, as part of an undergraduate student exchange programme. Between 2007 and 2012 he was a research assistant at the Laboratory of Hydraulic Constructions (LCH) at EPFL, involved in physical and numerical modeling concerning the design of intake structures, sediment flushing and flood protection concepts. In 2012, he obtained his doctorate in science on the subject of reservoir sedimentation in pumped-storage reservoirs. Currently he is working for IUB Engineering Ltd. in Berne as project engineer and project manager for hydropower and hydraulic engineering as well as river training and flood protection.

Dr Giovanni De Cesare is senior research associate and deputydirector of the Laboratory of Hydraulic Constructions LCH of the École Polytechnique Fédérale de Lausanne (EPFL), Switzerland. $\mathrm{He}$ is in charge of the hydraulic laboratory working in physical and numerical modeling in all domains of hydraulic structures and schemes. He specializes in various fields such as reservoir sediment management and turbidity currents; special hydraulic works; rapid transients in pressure systems; ultrasonic Doppler flow measurement and river training work. Giovanni De Cesare holds an MSc in Civil Engineering and a Ph.D. in technical sciences from the EPFL. He studied for one year at the Georgia Institute of Technology in Atlanta, USA. He is author of more than 120 scientific papers in peer-reviewed journals, publications and conference proceedings. He is lecturer in hydraulic and energetic networks at Master level as well as in hydraulic structures at bachelor level. He also teaches hydraulics, water networks and hydraulic schemes at the University of Applied Sciences of Western Switzerland. He is currently president of the Swiss Association of Soil Bioengineering.

Prof Dr Anton J. Schleiss graduated in Civil Engineering from the Swiss Federal Institute of Technology (ETH) in Zurich, Switzerland, in 1978. After joining the Laboratory of Hydraulic, Hydrology and Glaciology at ETH as a research associate and senior assistant, he obtained a Doctorate of Technical Sciences on the topic of pressure tunnel design in 1986. After that, he worked for 11 years for Electrowatt Engineering Ltd. in Zurich and was involved in the design of many hydropower projects around the world as an expert on hydraulic engineering and underground waterways. Until 1996, he was Head of the Hydraulic Structures Section in the Hydropower Department at Electrowatt. In 1997, he was nominated full professor and became Director of the Laboratory of Hydraulic Constructions (LCH) in the Civil Engineering Department of the Swiss Federal Institute of Technology Lausanne (EPFL). The LCH activities comprise education, research and services in the field of both fundamental and applied hydraulics and design of hydraulic structures and schemes. The research focuses on the interaction between water, sediment-rock, air and hydraulic structures as well as associated environmental issues and involves both numerical and physical modeling. Actually $19 \mathrm{Ph} . \mathrm{D}$. projects are ongoing at LCH under his guidance. From 1999 to 2009 he was Director of the Master of Advanced Studies (MAS) in Water Resources Management and Hydraulic Engineering held at EPFL in Lausanne in collaboration with ETH Zurich and the universities of Innsbruck (Austria), Munich (Germany), Grenoble (France) and Liège (Belgium). Prof. Schleiss is also involved as an international expert in several dam and hydropower plant projects worldwide as well as flood protection projects mainly in Switzerland. From 2006 to 2012, he was Director of the Civil Engineering program of EPFL and chair of the Swiss Committee on Dams (SwissCOLD). In 2006, he obtained the ASCE Karl Emil Hilgard Hydraulic Price as well as the J. C. Stevens Award. He was listed in 2011 among the 20 international personalities that 'have made the biggest difference to the sector Water Power \& Dam Construction over the last 10 years'. In 2014, he also became Council Member of International Association for Hydro-Environment Engineering and Research (IAHR) and chair of the Europe Regional Division of IAHR. For his outstanding contributions to advance the art and science of hydraulic structures engineering, he obtained the ASCE-EWRI Hydraulic Structures Medal in 2015. After having served as vicepresident between 2012 and 2015, he was elected president of the International Commission on Large Dams (ICOLD) in 2015.

\section{ORCiD}

Michael Müller (D) http://orcid.org/0000-0001-5723-6290

Giovanni De Cesare (D) http://orcid.org/0000-0002-1117-3180

Anton J. Schleiss (D) http://orcid.org/0000-0003-1559-5740

\section{References}

Anderson MA. 2010. Influence of pumped-storage hydroelectric plant operation on a shallow polymictic lake: predictions from 3-D hydrodynamic modeling. Lake Reservoir Manage. 26:1-13.

Anselmetti F, Bühler R, Finger D, Girardclos S, Lancini A, Rellstab C, Sturm M. 2007. Effects of Alpine hydropower dams on particle transport and lacustrine sedimentation. Aquat Sci. 69:179-198.

Bonalumi M, Anselmetti FS, Kaegi R, Wüest A. 2011. Particle dynamics in high-Alpine proglacial reservoirs modified by pumped-storage operation. Water Resour Res. 47:W09523.

Bouffard D. 2008. A new approach for studying small scale turbulence in the thermocline region of Lake of Geneva. Lausanne: Ecole Polytechnique Fédérale de Lausanne.

Bühler J, Siegenthaler C. 2003. Veränderungen im Oekosystem Brienzersee. Teilprojekt 3.2: Korngrössenverteilung, Zusammensetzung und Transport von Schwebstoffen im 
Grimselgebiet. Report, Amt für Gewässerschutz und Abfallwirtschaft des Kantons Bern (GSA), Bern, Switzerland.

Cook CB, Richmond MC, Serkowski JA. 2007. Observations of velocity conditions near a hydroelectric turbine draft tube exit using ADCP measurements. Flow Meas Instrum. 18:148-155.

Dorfmann C, Knoblauch H. 2008. ADCP measurements in a reservoir of a run-of-river Hydro Power Plant. In: Chara Z, Bares V, editors. 6th international symposium on ultrasonic Doppler method for fluid mechanics and fluid engineering; Prague. Czech Republic; p. 45-48.

Elci, E, Work, PA, Hayter, EJ. 2007. Influence of stratification and shoreline erosion on reservoir sedimentation patterns. J Hydraul Eng. 133(3):255-266.

Finger D, Bossard P, Schmid M, Jaun L, Müller B, Steiner D, Schäffer E, Zeh M, Wüest A. 2007. Effects of Alpine hydropower operations on primary production in a downstream lake. Aquat Sci. 69:240-256.

Finger D, Schmid M, Wüest A. 2006. Effects of upstream hydropower operation on riverine particle transport and turbidity in downstream lakes. Water Resour Res. 42:W08429.

Flotron AG. 2006. Grimselseeboden - Technischer Bericht: Bildflug, Geländemodell, Orthofoto. Report, Meiringen, Switzerland.

Gartner JW. 2004. Estimating suspended solids concentrations from backscatter intensity measured by acoustic Doppler current profiler in San Francisco Bay, California. Marine Geol. 211:169-187.

Girgidov AD, Loktionova EA, Prytkov VV. 1990. Effect of the operation of a pumped-storage station on the thermal regime of a natural water body. Hydrotech Construct. 24: 426-429.

Gordon L, Lohrmann A, Jonas T. 1999. Internal wave generation in lakes with very slow flow. In: Anderson SP, Terray EA, Rizoli JA, Williams AJ, editors. IEEE sixth working conference on current measurement; San Diego, CA. Stoughton: The Printing House; p. 212-215.

Goto T, Tsuchiyama S. 1998. Application of a hydraulic and in situ measurement for the construction of reservoir outlets. In: Holz KP, editor. 3rd International conference on hydroscience and engineering (ICHE); Cottbus/Berlin. University of Mississippi, Center for Computational Hydroscience and Engineering.

Graf WH. 1982. Storage losses in reservoirs. Int Water Power Dams Construct. 36:37-40.

ICOLD. 1989. Sedimentation control of reservoirs - guidelines. Bulletin 67, Paris: ICOLD.

Imboden D. 1980. The impact of pumped storage operation on the vertical temperature structure in a deep lake: a mathematical model. In: Clugston JP, editor. Proceedings of the Clemson workshop on environmental impacts of pumped storage hydroelectric operations; Clemson, South Carolina. Clemson (SC): US Dept. of the Interior, Fish and Wildlife Service; p. 125-146.
Kostaschuk R, Best J, Villard P, Peakall J, Franklin M. 2005. Measuring flow velocity and sediment transport with an acoustic Doppler current profiler. Geomorphology. 68: 25-37.

Laval B, Imberger J, Findikakis A. 2005. Dynamics of a large tropical lake: Lake Maracaibo. Aquat Sci. 67:337-349.

Lemmin U, Mortimer CH, Bauerle E. 2005. Internal seiche dynamics in Lake Geneva. Limnol. Oceanogr. 50: 207-216.

Lyons RG. 2004. Understanding digital signal processing. 2nd ed. Upper Saddle River (NJ): Prentice Hall PTR.

Müller M. 2012. Influence of in- and outflow sequences on flow patterns and suspended sediment behavior in reservoirs. In: Schleiss A, editor. Thesis 5471, Communication $\mathrm{N}^{\circ} 53 \mathrm{du}$ Laboratoire de constructions hydrauliques. Lausanne: Ecole Polytechnique Fédérale de Lausanne; 156 p.

Munnich M, Wuest A, Imboden DM. 1992. Observations of the second vertical mode of the internal seiche in an Alpine Lake. Limnol Oceanogr. 37:1705-1719.

Potter, DU, Stevens, MP, Meyer JL. 1982. Changes in physical and chemical variables in a new reservoir due to pumped storage operations. J Am Water Resour Assoc. 18: $627-633$

Schleiss AJ, De Cesare G, Jenzer Althaus J. 2010. Verlandung der Stauseen gefährdet die nachhaltige Nutzung der Wasserkraft. Wasser, Energie, Luft - eau, Énergie, Air 102:31-40.

Schott F, Johns W. 1987. Half-year-long measurements with a buoy-mounted acoustic Doppler current profiler in the somali current. J Geophys Res. 92:5169-5176.

Stevens C, Lawrence G. 1997. Estimation of wind-forced internal seiche amplitudes in lakes and reservoirs, with data from British Columbia, Canada. Aquat Sci. 59:115-134.

US Bureau of Reclamation. 1993. Aquatic ecology studies of Twin Lakes, Colorado, 1971-86: effects of a pumped-storage hydroelectric project on a pair of Montane lakes. Monograph No. 43. Denver, Colorado.

VAW. 1982. Auslaufbauwerk Grimselsee - Bericht über die hydraulischen Modellversuche. Zürich: VAW-ETH.

Vermeyen TB. (2002). Measuring selective withdrawal characteristics using an Argonaut acoustic Doppler velocimeter in Folsom Lake, California. In: Wahl TL, Pugh CA, Oberg KA, Vermeyen TB, editors. Hydraulic measurements and experimental methods. Estes Park, Colorado. American Society of Civil Engineers ASCE; p. 63-72.

Vermeyen TB. (2003). Acoustic Doppler velocity measurements collected near a municipal water intake, Lake Mead, Nevada-Arizona. In: Rizoli JA, editor. IEEE/OES seventh working conference on current measurement technology; San Diego, CA. Institute of Electrical and Electronics Engineers IEEE; p. 16-20.

Wolanski E, Gibbs R, Ridd P, Mehta A. 1992. Settling of oceandumped dredged material, Townsville, Australia. Estuarine, Coastal Shelf Sci. 35:473-489. 